Др Данијела Б. Васић

\title{
МАЈУШНИ ЈУНАК НАРОДНЕ ПРИПОВЕТКЕ, МОМОТАРО, КАО СИМБОЛ ЈАПАНСКОГ НАЦИОНАЛИЗМА
}

\begin{abstract}
Попут многих других усмених традиција, и јапанска има мајушног јунака који се бори против фантастичног непријатеља. Мoмот̄аро, приповетка о Дечаку из брескве, истиче национални идентитет Јапанаца и кључна је за формирање фолклористике у Јапану. У време доминације самурајске класе, наглашавала је лојалност, праведност и поштовање родитеља. С рестаурацијом царске власти, коришћена је у сврху пропагирања митских корена јапанског народа и лојалности према цару. У периодима ратова, уз подршку националиста, Момотароови противници су обликовани у складу с тренутним потребама. Демони (они) су постајали брадати Руси, покварени британски војници, а амерички председник - вођа демонског народа. И не само то, јапанске власти су у приповеци Момойаро пронашле оправдање за своје колонијалистичке тежње у циљу присвајања природних ресурса других држава.

Кључне речи: Момотаро, јапанска народна приповетка (мукащибанащи), Кокугаку школа, јапанска ратна пропаганда, јапански империјализам.
\end{abstract}

У академским круговима све је прихваћенија чињеница да нигде у свету не постоји „чиста раса“, „чиста етничка група“ и „чиста култура“. Ни Јапан није изузетак, будући да је, кроз сложену интеракцију различитих култура, током своје историје постао мултикултурално друштво. Ипак, у савременом јапанском друштву још увек живи веровање у „чисту јапанску крв“, у национализам који не признаје културне разлике. Шимамура Таканори објашњава (2003: 195) да је реч о „идеологији која истиче расно хомогену јапанску нацију““ Таквој идеологији су склони и неки научници. Јасно је, на пример, да су неки од радова обједињених у Теорије о аайанској кулииури (Нихон бункарон), ${ }_{1}$

${ }^{1}$ Нихонђинрон (Нихон бункарон, Нихон щиакаирон итд.) представља „дискурс који демонстрира јапанске културне разлике у односу на друге културе и јапанску културну 
писани управо под утицајем такве идеологије. Такође, у Великом речнику јайанскої фолклора (Нихон минзоку gаићииеен, в. FUкUтА: 1999), под одредницом „Јапанци“, помиње се искључиво део становништва који се бави земљорадњом, док се сви остали занемарују:

„Њихов етнички карактер заснован је на карактеру земљорадника. У принципу, основали су заједнице које су имале стално пребивалиште и живели су складно једни с другима. Осим тога, од људи у породицама очекивало се да помажу једни другима у наводњавању и у земљорадњи [...] То да је овај национални карактер проистекао из земљорадничког начина живота, јасно се види у њиховом савременом друштву“ (НАмАGUCHI 2000: 281).

Како бисмо могли да закључимо на који начин фолклористика, од својих почетака, гледа на културну различитост, важно је анализирати промене у ставовима оснивача ове науке, Кунија Јанагите (1875-1962). Јанагита се, на почетку својих истраживања, бавио управо културним различитостима. Томе сведоче (в. YANAGITA 1913, 1913-1914, 1914-1915) његови есеји о „планинским људима“ (санђин), о лутајућим свештеницима (хјохаку щикјоща) и шаманкама (мико), као и о дискриминисаним становницима забачених села (хисабеиу буракумин). „Планински људи“, како их је називао Јанагита, живели су на планинама и бавили су се ловом и култивацијом земљишта. Лутајући свештеници и шаманке обилазили су села и обављали верске обреде. Последњу категорију чине групе људи који су живели у тешко доступним подручјима и обављали дискриминисане делатности у систему ране модерне државе, нпр. месарским или кожарским занатом. Јанагита је развио теорије о историји и начину живота ових људи и закључио да су они „заправо потомци староседелаца, чије се етничко порекло разликује од порекла људи из равничарских предела“" (SHIMAMURA 2003: 197).

У наредној фази својих истраживања, Јанагита је установио сопствени приступ фолкору и отпочео систематско проучавање народне традиције. Јанагитино занимање се усредсређује искључиво на седелачко становиштво које се бави узгајањем пиринча (о томе нпр. AкASAKA 1994). Стручњаци ове радове описују као „монолитни фолклор под називом 'монизам узгајања пиринча" “(инасаку ићиіеенрон), будући да их је Јанагита засновао на „премиси да се култура јапанског острвља темељи на хомогеној традицији узгајања пиринча" (SHIMAMURA 2003: 198). Јасно разграничавајући монолитну јапанску нацију узгајивача пиринча, која га је надаље једино занимала, од других етничких група, попут староседелаца који су живели у удаљеним планинским селима, Јанагита је лишио свој рад озбиљног разматрања културних различитости. Штавише, своја каснија истраживања посветио је превасходно трагању за идентитетом јапанског народа и доказивањем његовог јединства.

јединственост у свету, како би се тиме успоставио јапански културни идентитет“ (MANABE - BEFU 1993: 89). 
И његови следбеници прихватали су ову „парадигму као саму по себи разумљиву“" (SHIMAмURA 2003: 199).

Насупрот Јанагитиним истомишљеницима, пак, стајали су научници као што је Орикући Шинобу (1887-1953), који је своја истраживања посветио управо лутајућим свештеницима и осталим групама с друштвених маргина. Неки научници сматрају да је на такве ставове утицало то што је у детињству имао прилике да се увери у тежак положај дискриминисаних група (в. нпр. SUZUKi 1991: 167; INUI 1992).

Пошто културна различитост у Јапану није тема овог рада, нећемо се бавити осталим научницима који су, или подржавали Јанагитине ставове, или им се супротстављали. Нагласићемо само да су многи произвољно заборављали одређене друштвене групе уколико се оне нису уклапале у њихове теорије, на исти начин како је Јанагита из својих фолклористичких истраживања искључио традицију „Планинских људи“ или староседелачког народа Аину. Други су, попут Цубои Хирофумија (1929-1988; в. Тsuвог 1979), признавали постојање других, али су ипак примат давали јединственој и хомогеној јапанској култури.

Идеје о јапанској нацији с монолитном традицијом имале су упориште у друштвено-историјским приликама друге половине 19. века. Меиђи период (1868-1912) започиње отварањем земље после дугогодишње изолације и доноси Јапану трансформацију из феудалне у модерну индустријску државу. Овај историјски период означила је и владина кампања под слоганом „цивилизација и просвећење“ (бунмеи каика), која није била ограничена само на политичку сферу, већ се проширила и на поље културе. Исход је било све веће интересовање јавности за све што је долазило са Запада.

Међутим, некритичко усвајање свега што је долазило са Запада, изазвало је и супротне реакције, па су се и највећи заговорници модернизације поново окретали традицији. Уз то, рестаурирана Меиђи царевина је чинила све да наметне и учврсти своју политику јединствене нације, која је кретала управо из центра модерне културе, Токија. У процесу претварања локалних социјалних група у грађане јаке централизоване државе, та иста држава је морала да пружи доказе о својој надмоћи над старим начинима живота и веровања, док је, у исто време, у тим старинама трагала за моделима којима ће најбоље приказати суштину јапанске нације. Настаје и нови жанр текстова који се баве питањима јапанског националног и културног идентитета, Нихонђинрон (Теорије о Јайанцима). Овим текстовима је заједничко то што деле убеђење у јединство јапанске нације и државе. Сада нови замах добија и израз Јамайо gамащи - , јапански дух“, скован још у Хеиан периоду (7941185) како би указао на аутохтоне јапанске културне вредности, насупрот вредностима других народа, пре свега кинеског. Симбол је напора да се локални „духови“ и богови реорганизују и сажму у један централни, национализовани , јапански дух“, отелотворен у новоустоличеном цару - модерном натприродном бићу и извору снаге јапанске нације. 
Трансформација Јапана у националну државу по модерним узорима тешко би била могућа да темеље нису поставили, између осталих, следбеници школе Кокуїаку (Наука о Јапану). Овај академски покрет појавио се у Токугава (Едо) периоду (1603-1867), као одговор на синоцентричне новоконфуцијанске теорије. Следбеници покрета покушали су да поврате јапанску културу која је постојала пре доласка будизма и конфуцијанизма, ослањајући се на аутохтону јапанску религију, шинто, и на јапанску древну књижевност. Сматрали су да је јапански национални карактер природно чист и да ће истински јапански дух открити свој прави сјај тек када се отклоне страни утицаји. Зато су се заинтересовали превасходно за филолошку анализу древних јапанских текстова ${ }^{2}$ и класичне књижевности, покушавајући да одвоје аутохтоно јапанско, од преовлађујућих кинеских наноса. Циљ им је био опоравак изворних националних вредности. Настојали су да открију изворни дух Јапана како би се коначно могла дефинисати јединственост националне, у односу на стране културе и омогућити повратак (привидно) нетакнутим етничким коренима. Стога је сасвим логично то што су се суштина и циљеви ове, као и других сродних школа, пренели и у Меиђи период, постављајући основу јапанском национализму који је све више јачао.

За повратак коренима се залагао и Кунио Јанагита. У складу с потребом да Јапанцима открије њихово наслеђе, била је и његова тежња да нагласи вредност јапанских народних приповедака (мукащибанащи). ${ }^{3}$ Премда је био заинтересован за све аспекте културе сеоских заједница, Јанагита је управо у тим бисерима усмене књижевности препознао средство за откривање унутрашњег света јапанског народа.

Почетком тридесетих година 20. века, у време када је мењао назив својих проучавања из кјоgо кенкју (проучавање локалне средине) у минзокугаку (фолклористика), Јанагита је одабрао једну познату народну приповетку и посветио јој посебну пажњу. Била је то приповетка Момойаро - Дечак из брескве (момо - бресква; йаро - уобичајени суфикс у мушким именима, са значењем „најстарији син“), коју је он сматрао аутохтоном јапанском, за разлику од многих других које су настале ван Јапана.

Велико занимање Јапанаца за народне приповетке изазвала је управо Јанагитина студија посвећена овој народној приповеци, Момот̄ароово роЂење из 1933. године (Момойаро но йанђо, YANAGITA 1948, 1990), која је, уз

\footnotetext{
${ }^{2}$ Међу њима је и најстарија сачувана књига у Јапану, Кођики (Зайиси о gойађајима из

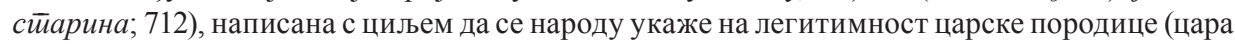
Тенмуа), који је преузео власт победивши законитог престолонаследника у рату у ери Ђиншин (672). Настојећи да створи јаку, централистички уређену државу, цар Тенму доноси одлуку да се од предања која су усмено преношена у покрајинама широм земље сачини јединствена верзија званичног родослова, којим је могао да оправда своје божанско порекло и докаже легимитет државне власти на челу са царом (в. OGIHARA, Konosu 1992; Коъики 2008).

3 Под појмом мукащибанащи обједињени су сижеи који по својим жанровским одликама имају паралеле у различитим српским врстама народне књижевности. Осим бајкама, неки одговарају српским предањима, а други шаљивим причама (о томе више у ВАсић 2016).
} 
Сйисак јайанских нарояних йрийовеgака (Нихон мукащибанащи меии; YANAGITA 1971), поставила темељ јапанске фолклористике. На почетку студије, Јанагита се сећа своје посете музеју у Фиренци, где је упоредио Ботичелијево Рођење Венере с рођењем Дечака из брескве. Поредећи познату јапанску приповетку с класиком италијанског сликарства, желео је да подсети на вредност усмене књижевности, али и да укаже на још једно рађање - нове научне дисциплине, фолклористике (минзокуїаку). У студији Момот̄ароово рођењь садржан је зачетак Јанагитиног систематичног, компаративног проучавања народних приповедака. Он анализира више десетина јапанских приповедака и пореди их с добро познатим европским причама како би јапанску културну баштину поставио напоредо с доминантном западном, а свом главном објекту изучавања, јапанским народним приповеткама, дао престиж потребан за формирање нове научне области.

Момотиаро је уједно и једна од најпознатијих јапанских народних приповедака, мукащибанащи. ${ }^{4}$ Такође, једна је у низу прича о мајушном детету (ћuисако), која има паралеле у традицијама широм света. Такво дете обично нека виша сила додељује старом, бездетном брачном пару. Мајушни јунаци су најчешће дечаци (Момотаро, Исунбоши, Гобутаро, Ћикаратаро), али то може бити и девојчица, попут Урикохиме или принцезе Кагујахиме, јунакиње Приче о секачу бамбуса. 5 Заједничка особина ових јунака је да су мали растом и да су рођени на чудесан начин. Момотаро је рођен из брескве, Урикохиме из диње, Гобутаро из јагодице на прсту, Ћикаратаро из прљавштине бабе и деде лењиваца, а Кагујахиме из стабљике бамбуса. Често су обдарени нарочитим способностима: изузетном снагом, памећу или лепотом.

Ови мајушни јунаци народних приповедака у суштини представљају типског јунака који успева да убије чудовиште. На овом свету се појављују као одговор богова на молитве, а с циљем да успешно разреше свакојаке невоље. У позадини таквог лика лежи мајушно божанство које силази на земљу како би смртницима донело добробит, на које наилазимо већ у најстаријем сачуваном делу јапанске књижевности, Кођикију. Бог Сукунабикона (Мали бог земље) ${ }^{6}$ долази из прекоморске утопије, Земље вечности, и помаже богу Оокунинушију при стварању земље. Сукунабикона обитава у Земљи вечности

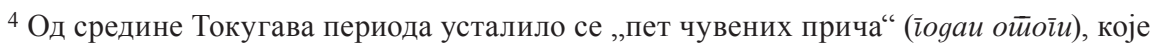
се називају и „причама о пет елемената“ (земља, вода, ватра, ветар, небо). То су: Момойаро, Каћи-каћи йланина, Врайчица којој су одсекли језик, Деgа цвейања цвећа и Сукоб мајмуна и краба. Јапаном су се шириле углавном у виду сликовница. (Више о јапанским народним приповеткама, мукащибанащu, и преводе приповедака с јапанског језика в. ВАсић 2016; 2018).

${ }^{5}$ Прича о секачу бамбуса - Такейори монойайари (в. ПРИчА О СЕКАчУ БАмБУСА 2010;

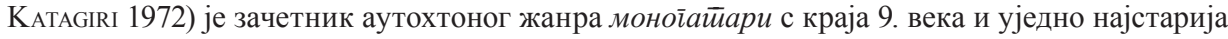
фантастична прича у Јапану, gенки моноїайари (о томе више у студији Месечева йринцеза, в. ВАСй 2013).

${ }^{6}$ Сукунабико је патуљасти бог, који је помогао богу Оокунинушију. Заједно су лечили и гајили биљке и усеве. Једнога дана се попео на зрелу стабљику проса, која се савила под тежином, а онда га одбацила у небо. Кажу да се тај умиљати мајушни бог и даље појављује 
као дух предака и управља плодношћу смртника (о томе више у ВАсић 2008; 2013; Акима 1993: 107 и даље).

И у српском народу је омиљен мајушни јунак из народних приповедака, превасходно бајки. Чудесно рођен, најчешће долази као награда бездетном брачном пару или једном родитељу. Обично је одговор на молитву вишој сили, као у приповеткама Биберче, Бисерко, Син као йалач, Девеgесей и gевет̄ синова, Ко је најсрећнији на свијейу и др (в. Караџић 1977; Чајкановић 1999). Као и у јапанским приповеткама, и у српским бајкама махом се чудесно рађа син. Следи његов подвиг, а након тога срећан крај као жанровски императив. Бајке о чудесно рођеној девојци веома су ретке, а у њима је образац ближи моделима о прогоњеној невести, мада девојку може угрожавати и лажна јунакиња.

Момойаро је једна од најпознатијих таквих прича у Јапану. Дуги низ деценија препричавају је и стари и млади. Своје верзије су давали и познати књижевници, а мотиве анализирали познати научници. Уз то, варијанте ове приче уткане су у локалне историје, нарочито у префектурама Окајама или Гифу, чему је допринео развој туризма и проучавања локалне средине (кjogo кенкjy) у предратном периоду. Док су проучаваоци локалне средине (кjogo кенкjущua), причу Момойаро сврставали у легенде ( gенсеиу), ${ }^{7}$ Јанагита Кунио ју је истицао као репрезентативну јапанску народну приповетку (мукащибанашu). Своја проучавања о народним приповеткама засновао је управо на анализи овог сижеа, а његови закључци су истакли значај ове приповетке за национални идентитет Јапанаца. Захваљујући Јанагитиним радовима, једна, стандардизована варијанта ове приповетке постала је позната широм Јапана.

Главни јунак истоимене приповетке, Момотаро или Дечак из брескве, назван је тако јер је рођен из брескве коју виша сила шаље старом брачном пару без деце. Како дечак одраста, открива своју чудесну снагу. У то време, демони (они), који живе на удаљеном острву, долазе до Момотароовог села, пљачкају и отимају људе. Млади Момотаро одлучује да оде до њиховог острва како би се с њима суочио и потчинио их. Старци му дају храну за пут, и то кнедле од проса (киби gані̄o). Успут се Момотару придружују пас, мајмун и фазан и, у замену за укусне кнедле од проса, постају његови вазали. Заједно стижу до острва, побеђују демоне и узимају њихово благо (превод приповетке в. у: ВАсић 2016; 2018).

Очигледно је да мукашибанаши Момойаро садржи све елементе (европске) народне бајке. Ту је, пре свега, чудесно рођено мајушно дете, мудро и сналажљиво, које старом брачном пару доноси срећу и весеље, а уз то и богатство. Сасвим у складу с особинама овог лика у бајци, мајушни јунак се упушта у пустоловине, а на путу има и (чудесне) помоћнике. У борби против

како би одвео људе до топлих извора. „То је од њега и очекивано јер је познат по својој благости, љубазности, као и по својој видарској вештини““ (PIGGOTт 1969: 26).

${ }^{7} \mathrm{O}$ жанровима у јапанској усменој прози, као и више о самој приповеци Момойаро, в. ВАСић 2016. 
злог противника излази као победник и прича има срећан крај, што је такође жанровска одлика народне бајке.

Широм Јапана постоје многобројне варијанте приповетке о дечаку из брескве. Разлике су обично у неким детаљима: у боји брескве, у Момотароовим сапутницима (помоћницима) или у начину на који је рођен. Негде се јавља и мотив чудесног раста. Као што ће показати даља анализа, често су те различитости условљене друштвено-политичким окружењем у ком варијанта настаје, поготово уколико је причи дата функција пропагандног оруђа.

Уколико покушамо да сагледамо генезу приче Момойаро, можемо закључити да је прошла дуг пут до тренутка док није постала најпознатија народна приповетка (мукащибанащи) у Јапану. Јанагита је сматрао (1948: 257-259) да је Момойаро, као и велики број других приповедака, настала средином Муромаћи периода (1336-1573) и да је од тада усмено преношена у сеоским заједницама, далеко од утицаја из престонице где је стварана „званична култура“. У писаном облику се први пут појавила у време када је ратничка класа преузела власт у Јапану. Записивачи су се трудили да истакну најважније друштвене вредности тога времена: лојалност, праведности и поштовање родитеља, те је прича постала узор сваком Јапанцу. Прво је штампана у илустрованим књигама, и то и као сликовница за децу (нпр. акахон) и као илустрована књига за одрасле (кибјощu). ${ }^{8}$ Прича о дечаку из брескве обрела се и на хоризонталним свицима (емакимоно). ${ }^{9}$ Пронашла је свој пут и до луткарског позоришта (бунраку или нинїо ђорури). Призоре из приповетке можемо видети и на укијо-е графикама и сликама (од 17. до 19. века), које су, између осталог, приказивале и теме и мотиве из историје и из народних приповедака.

Проучавања Јанагите Кунија истакла су значај ове приповетке за национални идентитет Јапанаца. Према Јанагити (1997: 257), приповетка Момойаро се развијала заједно с јапанским народом. Пратила је његове миграције све дубље у копно, ближе планинама, где су се развила веровања о духовима (боговима, ками), који су с небеса сишли на врхове планина, а одатле повремено посећивали свет људи. Зато и не изненађује чињеница да су Јапанци „осмислили духа који у наш свет улази плутајући низ планински поток.“ (YANAGITA 1997: 258) Јанагита сугерише (1997: 259 и даље) да је Момотароово рођење из брескве одраз народног веровања у контакте између света људи и света богова. Другим речима, оригинална верзија ове приче пре би се могла назвати митом (uнва), него народном приповетком (мукащибанащи)). Јапанска усмена традицији заиста обилује приповеткама с наглашеним религијским и митолошким елементима, што резултира донекле нејасном

${ }^{8}$ Кибјощи се сматрају првим стриповима за одрасле у Јапану, јер су текст и дијалози стајали у празним пољима на слици, која је била преко целе стране.

${ }^{9}$ Емаки су били популарни од 11. до 16 . Века. Кроз причу у сликама описивали су чувене битке, религиозне мотиве, теме из чувених јапанских класика, али и народне приповетке и приче о натприродном. 
разликом између мита и приповетке. Јанагита то користи у истицању јапанске супериорности, будући да извлачи закључак да су „као извори историје религије, јапанске приповетке вредније од приповедака из других земаља“ (YANAGiTA 1990: 11-12).

Истовремено, Јанагита покушава да одгонетне промене кроз које су временом пролазиле приповетке о мајушним јунацима (YANAGITA 1990). Кад је реч о причи о Дечаку из брескве, њена оригинална верзија је одавно нестала, али он сматра (1990: 192) да оригиналне идеје остају непромењене и да се ипак могу препознати у приповеткама. Таква је, рецимо, идеја да само побожни људи могу бити благословени дететом или да дете може допловити реком (YANAGITA 1990: 193).

Друге сродне приповетке разликују се од приповетке Момойаро по томе што (чудесно) одрастање мајушних јунака води ступању у најбоље бракове, с циљем да добију потомство и постану зачетници лозе. Путовања сличних европских јунака често подразумевају много више од освајања блага и повратка кући. Благо може бити средство којим ће се добити жена, дом и деца, и тако обезбедити срећна будућност. Према Јанагити, овај део је „вероватно намерно изостављен из савремене приче [ханащu $]$, не само зато што је у њој главни лик дете, већ и због тога што њену публику чине деца“" (1997: 257). Он изводи закључак да у претпостављеном оригиналу Момотаро ипак узима жену. Сматра да новије приповетке, које су забележене у уџбеницима и у књигама за децу, нису ништа друго до искварене старије варијанте, па самим тим нису аутентичне (YANAGITA 1997: 258). Приповетка Момойаро носи све најважније елементе једне метаприповетке: ${ }^{10}$ рођење, детињство, животне изазове преброђене уз помоћ животиња-помоћника и коначно, превазилажење препрека. Једино што јој недостаје јесу брак и потомство. Јанагита се није лако мирио с овом „омашком“. Био је чврсто уверен да је раније морала постојати аутентична варијанта, која је укључивала потрагу за женом (иума мотиоме). Управо из тог разлога је у Приручник за сакуйљање народних йрийовеgака (в. YANAGITA, SEKI 1936) укључио необичну варијанту овог сижеа, у којој недостају животиње-помоћници, а Момотаро креће на пут да ослободи заробљену принцезу. Успева у томе, враћа се кући са женом и богатством и од тада живи срећно у свом селу.

Јанагитини противници су тврдили да ове идеје ипак нису поткрепљене доказима. Јер, иако је сам Јанагита помогао да се широм Јапана сакупе

${ }^{10}$ Свој концепт да локалне приповетке треба посматрати као један сегмент веће групе приповедака, која представља део јапанске културе кроз време и простор, Јанагита је применио и на Приручник за сакуйљање нарояних иррийовеgак (YANagita, SeKi 1936). Деведесет девет забележених приповедака (не рачунајући стоту, додатну) могло се читати појединачно, као засебни сижеи. Али, посматране заједно, чиниле су једну метаприповетку. То значи да су поређане тако да прате логичан след елемената једне народне приповетке, који одговара циклусу човековог живота. Почиње рођењем и детињством, затим следе разни изазови у животу, обично преброђени уз помоћ помоћника, и на крају се све окончава срећно, најчешће браком и децом. 
варијанте ове приповетке, од више стотина забележених, само мали број укључује финални сегмент с добијањем жене, да би и за њих каснији научници установили да је реч о контаминацији с другим приповеткама.

Јанагита је упорно инсистирао на изворним националним вредностима. Зато је игнорисао било какве упливе тема и мотива из Кине, сматрајући да културне карактеристике, за које се претпоставља да су јединствено јапанске, не могу никако да потичу из иностранства. Упркос томе, у Кини се могу наћи сижеи с мотивима сродним онима из приповетке Момойаро. Можда је најпознатија таква прича, Краљ мајмуна, у којој се издваја и заједнички мотив брескве (бесмртности). С друге стране, неке варијанте јапанске приповетке почињу тиме што старац и старица поједу брескву од које се подмладе, па добију сина.

У приповеци препознајемо и таоистичку идеју да човек треба да живи у хармонији и равнотежи с природом. Животиње које су Момотароови чудесни помагачи: пас, мајмун и фазан, у природи не би имале ничег заједничког, али су се овде удружиле, и то са заједничким циљем. Такође, у одређеним варијантама демони траже опроштај и обећавају да више неће чинити зло. То је сасвим у складу с таоистичким веровањима да у сваком бићу постоји добро и лоше ( $и н$ и јані) $)$, те да свако има способност да чини и добро и лоше. У томе што поражени непријатељ увиђа своје грехе и тражи искупљење, препознајемо и одјек идеја будистичке секте Чиста земља, као и вере у милост Буде Амиде. У неким старијим и ређим верзијама, стилизовано је и погубљење демона од стране праведника Момотароа, као још један пример идеје да се добро награђује, а зло кажњава.

Амидистичко веровање у Чисту земљу доносило је и убеђење да људи не могу достићи просветљење без божанске помоћи. Старац и старица не губе веру, усрдно се моле и управо зато су награђени, а Момотаро се назива „дар од Бога“ (сазукаримоно). И Јанагита пише о томе да јапанске приповетке с мотивом натприродног рођења (иђо йанђо), повезује лик мајушног детета (ћиисако), које је производ срећног рођења и натприродног наслеђа: „Мајушно дете одраста изненада, под одређеним условима и у одређено време, а онда обавља веома тешке задатке, које смртник не би могао обавити. На тај начин оно усрећи деду и бабу, који су га брижно одгајали. Ова деца су дарована само људима који поседују чврсту веру, онима који се моле“ (YANAGITA 1990: 68).

Уколико занемаримо сижее прилагођене деци, за мукащибанащи се не може рећи да су то увек приче за децу, било због мрачне атмосфере, било зато што се баве проблемима одраслих. Момот̄аро почиње тиме како су старац и старица, који нису имали деце, добили (мајушног) сина. У средњем веку, синови су породици доносили социјалну сигурност јер су осигуравали наставак лозе, а родитељи су имали некога ко ће се бринути о њима. На помен бездетних родитеља, тадашњи слушалац усмене приповетке саосећао je с породицом која се обрела у неприликама. А кад би чуо да је пар добио прилику да усвоји сина, ето разлога за неописиву радост. Лоза се настављала, 
што је била најважнија породична дужност у друштву којим су владале конфуцијанске идеје. Приповетка Момотиаро је управо наглашавала „значај потомства, продужетка лозе и то колико је важно да се дечаци отисну у свет како би постали мушкарци“" (KAHARA 2005: 87).

Јасно је да „Момотаро“ открива мотиве из јапанске, али и из кинеске традиције. Истовремено, различите варијанте углавном носе одраз друштвено-историјских околности. Под утицајем средњовековних конфуцијанских и таоистичких идеја, у то време популарне варијанте немају крај уобичајен за народну бајку. Момотаро није живео срећно до краја живота с лепотицом чију је руку освојио, већ се враћа кући како би се надаље бринуо о родитељима који су га усвојили. Поразио је натприродне непријатеље и тако повратио част својој породици и свом селу, а за то је добио признање од господара, па чак и од цара.

Од како су власти почеле причу да користе у пропагандне сврхе, било ради наметања конфуцијанских вредности или учвршћивања националног духа, заборављене су варијанте у којима је Момотаро лењи момак који неће да обавља своје дужности или несташко који креће у авантуру да би од демона украо благо.

Прича о Дечаку из брескве позивала је Јапанце да се врате завичајним вредностима, али и да бране земљу од нецивилизованих народа. Иу ратничким еповима, омиљеним у Токугава периоду, јавља се јунак-ратник, који путује у далеку земљу како би потчинио урођенике, баш као што то чини и Момотаро. У најстаријој верзији књиге Хойен моноїат̄ари из 1318. (в. MURASE 1967: 195), снажни стрелац, Минамото но Таметомо, види птицу која га води ка острву Изу, баш као што фазан води Момотароа. Кад Таметомо коначно стигне на острво, тамо наилази на нека чудна бића, космата и висока. Нису говорили разумљивим језиком, нису били цивилизовани и нису се бавили земљорадњом. Таметомо је ипак успео да се споразуме с њима и сазна да је стигао на Демонско острво (Они і $а$ ㅆ имa). И у једној од легенди, чувени самурајски заповедник, Минамото но Јошицуне (1159-1189), одлази до острва на северу земље, према некима то је Хокаидо, (ANTONI 1991: 174), где успева да савлада чудне демоне, па чак и да их научи да живе јапанским начином живота.

Крајем Токугава периода мења се читалачка публика, па књижевност више није намењена само врхушки ратничке класе и аристократији, већ почиње да се прилагођава новој класи трговаца. Појављују се различити типови илустрованих књига, у којима су најчешће штампане појединачне приче, док су се сижеи обично заснивали на адаптираним народним приповеткама. С вредностима које је истицала, и прича Момотиаро је овде нашла своје место. Писац Кјокутеи Бакин (1767-1848), самозвани учитељ националне историје, стилизовао је мотиве из ове приче, тако да његови јунаци одлазе до далеких острва, где покоравају демонске урођенике. Бакин је искористио овај мотив и за то да Русе прикаже као варваре са севера (ZOLBROD 1966: 24).

У наредном, Меиђи периоду, дошло је до великог интересовања за јапанске народне приповетке, па и за причу о Дечаку из брескве. Нашла се у 
збиркама за децу, које су у то време биле веома популарне и штампане су у великим тиражима. Постала је и део званичних школских уџбеника, будући да се у читанкама, одмах на почетку (1887), нашла раме уз раме с митом о стварању из најстарије књиге, Кођики. Спроводећи програм обавезног школовања деце, власти су припремиле стандардизоване уџбенике, који ће бити у употреби широм земље. Истовремено су користиле централизовани образовни систем како би пропагирале ,јапански дух“ (Јамайо gамащи). У ту сврху, у читанке је уврштено и неколико добро познатих народних приповедака. Сижеи су преузети из писаних извора, рецимо из поменутих дечјих сликовница, штампаних током Токугава периода. Такве записане приповетке, из дечијих збирки и из читанки, проузроковале су појаву различитих варијанти широм Јапана, које су на тај начин настављале свој развој у усменом стваралаштву. Момотаро је постао национална икона, а из приче о њему, поуке су извалачили јапански ђаци у централизованом школском систему. Момотарова доброта, наклоност и оданост према својим старим родитељима, представљале су савршен узор младим Јапанцима.

Свеобухватне промене у Меиђи периоду донеле су и трансформацију приче Момойаро. Искоришћена је у сврху пропагирања митских корена јапанског народа, а раније истицана оданост према господару и породици, сада је замењена лојалношћу према цару и свом народу. Издвојила се једна од варијанти приповетке, и то она која је садржавала митске елементе, што је властима омогућило да причу доведу у везу с познатим митовима и легендама како би се појачао национални сентимент. Узмимо за пример брижљиво одабрани мотив кнедли од проса (киби gані̄o - „најукуснијих кнедли у Јапану“, ВАСић 2016: 120; 2018: 9). Момотаро задобија оданост својих пратилаца - животиња само захваљујући тој, типично јапанској посластици, те се и овај мотив може схватити као алегорија супериорности јапанске културе. Кад је било потребно приповетку употребити у политичке сврхе, онда се прибегавало комбиновању елемената мита, легенде и усмене традиција, како би се избрисала граница између натприродног и реалног. То је био кључни концепт у развоју национализма током Меиђи ере.

С развојем фолклористике и с растом интересовања за усмену књижевност, све је већи број збирки народних приповедака, које садрже различите варијанте познатих сижеа. Такав је случај и с приповетком Момойаро. Међу сижеима забележеним почетком 20. века, откривамо и оне које се никако не би уклопили у конфуцијанске и будистичке идеале претходног, Токугава периода. Сада Момотаро и његови помоћници одбацују самурајску одећу и облаче униформе јапанских војника. Нагласак је на приказу Момотароа као предузимљивог вође, који је у стању да приволи, иначе неспојиве и независне ликове (припаднике потпуно различитих врста животиња), у организовану силу. Овај мотив ће бити коришћен у националистичком покрету како би се објасниле тежње јапанских империјалиста да почетком 20. века, под изговором заједничког просперитета, уједине и уједно покоре народе источне и јужне Азије. Момотароово делање симболизује Јапан, божанску 
земљу, а његови вазали: пас, мајмун и фазан, симболизују друге азијске земље, које треба да следе Јапан.

У време кинеско-јапанског рата (1894-1895), Момотаро постаје јапански херој због свог предузимљивог, авантуристичког духа, док су демони (они), заправо непријатељи империјалног Јапана. Пре него што крене на пут, Момотаро обећа да ће демонима отети све благо. Другим речима, не одлази он на далеки пут само да би непријатеље покорио, тј. да би цивилизовао дивље и неуке. Он показује спремност да одузме, или боље рећи опљачка, туђу својину, чиме се открива и оправдава империјалистички начин размишљања. На тај начин, прича о Дечаку из брескве постаје алегорија јапанског империјализма.

Свима добро познати мајушни јунак истакнут је као симбол нације, отелотворење јапанских идеја о снази, праведности, оданости и храбрости. Иде се и корак даље, па Момотаро постаје оруђе ратне пропаганде. Један од првих примера је варијанта ове приповетке, под називом Меиђи Момо$\bar{u}$ аро из 1904. године (NomURA 2000: 39), где су демони (они) које Момотаро побеђује, представљени као брадати Руси. Надаље се термин „они“ користи као заједнички назив за народе с другачијим традицијама и обичајима.

У периодима ратова, јапанске вође су, уз свесрдну подршку ултранационалиста, обликовале Момотароове противнике у складу с тренутним потребама и ситуацијом. Мићио Намекава примећује (1981: 206) да у старијим варијантама није дато објашњење зашто је Момотаро морао да покори демоне (они) на њиховом острву. Били су покорени једноставно зато што су они, симбол зла и човекови непријатељи, које је требало уклонити. Међутим, како је током Меиђи периода Момотаро постајао симбол идеалног јапанског дечака, требало је водити рачуна о сваком детаљу у вези с њим. „Идеални јунак једноставно не истребљује некога без доброг разлога“ (NAMEKAWA 1981: 17-18). Згодно је када тај разлог одражава вредности одређеног историјског периода. Тако су у варијанти забележеној у збирци Нихон мукашибанаши (Јайанске нарояне иррийоветике) Иваје Сазанамија, они елиминисани не само зато што су зли, већ зато што „се не покоравају благонаклоној владавини царског Јапана и чине штету у Јапану. Они отимају људе и поједу их, одузимају им драгоцену имовину, тако да су они најмрскија створења на свету“ (IwAYA 2001: 19). И док је јапанска пропагандна машина непријатељске логоре представљала као демонска острва, јапанска војска је у азијским земљама чинила таква зверства да се понашала управо као демони из приповетке.

Почетком Другог светског рата, у Јапану су странце углавном приказивали као приглупа бића - полуљуде, полузвери, док су непријатеље државе - „зле савезничке снаге“, описивали као (рогате) демоне, они. Под будним оком државне цензуре, стрипови, часописи и анимирани филмови користили су и мотиве из приповетке Момойаро како би подржали јапанске колонијалне циљеве и подстакли национализам. Цртачи стрипова (мані̄a) цртали су рогове Рузвелту, Черчилу и Стаљину, користећи њихове ликове у циљу ратне пропаганде. Амерички председник је заправо прерушени демон, вођа демонског народа. Године 1945. Јапанци су имали прилике да гледају (по не- 
кима) најстарији анимирани филм (аниме), у трајању од 74 минута - Момо-

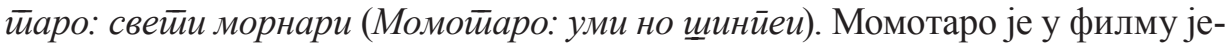
дини људски лик. Бори се против демона, а то су британски војници, који пију и коцкају се и притом лажу и варају. Епилог филма приказује децу како се играју скакања падобраном. Пењу се на дрво и скачу на земљу где су исцртане контуре Америке, што је био јасан показатељ шта треба да буде мета нових јапанских генерација. Јер, из јапанске перспективе, Американци су били зли они с другачијим обичајима, империјалистичка демонска сила која спроводи инвазију на Азију, на коју је претендовао Јапан.

Као што је Момотаро преотео благо демона на њиховом острву, тако је и Јапан присвајао природне ресурсе других држава. Јапан је очекивао да ће без већих проблема преузети контролу над Кином, али је наишао на неочекивано јак отпор, што је резултирало исцрпљивањем ионако оскудних ресурса. Према јапанском плану за прибављање природних ресурса, превасходно нафте, војска је тежила да колонијализује подручја Северне Азије, док је јапанска морнарица настојала да присвоји ресурсе Југоисточне Азије. Јапан је знао да ће то резултирати сукобом са Сједињеним Државама, али су апетити морали бити задовољени. Међутим, подухват се завршио неуспехом и катастрофом.

Па ипак, ти исти они, против којих се борила јапанска војска, у складу са својом демонском природом, имају способност трансформације. Тако су се и амерички они претворили у најјачег јапанског стратешког савезника и економског партнера у послератном периоду, показујући своју беневолентну страну и пружајући јапанском народу све што му је било потребно. Таква промена улога намеће питање: Ко су уопште ти људи с другачијим обичајима, који су живели ван домета царске власти? Могу ли се заиста тако олако етикетирати као демони, они? С таквим заокретом и променом перспективе, и приповетка Момойаро губи функцију оруђа национализма и пропаганде. Када је, на све то, после рата цар обзнанио нацији да није божанско биће, већ смртник, срушила се читава парадигма Јапанског царства као натприродног и божанског.

\section{ИЗВОРИ}

ВАсић, Данијела (прир.). Мукащибанащи - јайанске нарояне йрийовейке. Превод с јапанског језика, предговор и напомене Д. Васић. Београд: Танеси, 2018.

ВАсић, Данијела. Јайанске нарояне йрийовейке - Nihon no mukašibanaši. 1. О јапанским народним приповеткама (студија, библиографија, индекс и др.); 2. Јапанске народне приповетке (избор, превод с јапанског језика, коментари и напомене Д. Васић). Београд: Танеси, 2016.

КАРАџић, Вук Стефановић. Срйске нарояне йрийовјейке. Београд: Нолит, 1977.

Ковики (Зайиси о древним gоїађајима). Оо но Јасумаро (прир.). Превод са старојапанског језика Х. Јамасаки-Вукелић, Д. Васић, Д. Кличковић и Д. Глумац, Београд: Рад, 2008. 
ПРИчА О СЕКАЧУ БАмБУСА (Такейори моноїайари). Прев. са старојапанског језика Д. Васић и Х. Јамасаки-Вукелић. Поговор Д. Васић. Београд: Танеси, 2010.

ЧАлкановић, Веселин. Срйске Наровне Прийовейке. Београд: Гутенбергова Галаксија, 1999.

IwaYA Sazanami. Nihon mukashibanashi. Ueda Nobumichi ed. Tokyo: Heibonsha (Toyo bunko), 2001.

KATAGIRI, Yoichi et al. Nihon kotenbungaku zenshu 8: Taketori monogatari, Ise monogatari, Yamato monogatari, Heichu monogatari. Tokyo: Shogakukan, 1972.

Ogihara, Asao, Konosu, Hayao (ed.). Nihon koten bungaku zenshu. Vol. 1: Kojiki: Jodai kayo, Tokyo: Shogakukan, 1992.

\section{ЦИТИРАНА ЛИТЕРАТУРА}

AkasaKa, Norio. Yanagita Kunio no yomikata: Mo hitotsu no minzokugaku wa kano ka. Tokyo: Chikuma Shobo, 1994.

Акима, Тошіо. The Myth of the Goddess of the Undersea World and the Tale of Empress Jingu's Subjugation of Silla. Japanese Journal of Religious Studies 20/2-3, 1993.

Antoni, Klaus. Momotaro (The Peach Boy) and the Spirit of Japan: Concerning the Function of a Fairy Tale in Japanese Nationalism of the Early Showa Age. Asian Folklore Studies 50 (1991): 155-188.

CAmpbell, Joseph. The Masks of God: Primitive Mythology. New York: Viking Press, 1959. FukutA, Ajio et al., eds. Nikon minzoku daijiten 1 Tokyo: Yoshikawa Kobunkan, 1999. Hamaguchi, Eshun. Nihonjin (2). Fukuta Ajio et al. eds., 2000.

INUI, TAKETOSHI. Hisabetsu buraku densho bunkaron josetsu: Orikuchi Shinobu o do yomu ka. Buraku kaiho kenkyu 87, 1992.

KaHARA, Nahoko. Mirai e muketa dento tsukuri - 'Momotaro densetsu chi' Okayama no keisei. Momotaro wa ima mo genki da. Okayama: Okayama Momotaro kenkyykai, 2005, 108-149.

Manabe, Kazufumi, Harumi Befu. Japanese Cultural Identity: An Empirical Investigation of Nihonjinron. Contemporary Japan. < https://doi.org/10.1080/09386491.1993.1182 $7036>10.01 .2021$.

MuraSE, Miyeko. Japanese Screen Paintings of the Hogen and Heiji Insurrections. Artibus Asiae. Vol. 29. No. 2/3, 1967.

Namerawa, Michio. Momotaro-zo no hen'yo. Tokyo: Tokyo Shoseki, 1981.

Nomura Junnichi. Shin Momotaro no Tanjo. Tokyo: Yoshikawa Kobunkan, 2000.

PIGGOTT, Juliet. Japanese Mythology. London: Hamlyn, 1969.

ReIDER, Noriko T. Japanese Demon Lore: Oni, from ancient times to the present. Logan, Utah: Utah State University Press, 2010.

Shimamura, Takanori. Cultural Diversity and Folklore Studies in Japan: A Multiculturalist Approach. Asian Folklore Studies. Vol. 62, No. 2. Topics in Japanese Folklore Studies (2003): 195-224. 
Suzuki, Mitsuo. Yanagita, Orikuci igo. Tokyo: Sekai Shoin, 1991.

Yanagita, Kunio. Fujo ko. Kyodo kenkyu, March 1913 - February 1914. In Yanagita Kunio zenshu. Vol. 11. 305-415, Tokyo: Chikuma Shobo.

Yanagita, Kunio. Kebozu ko. Kyodo kenkyu, March 1914 - February 1915. In Yanagita Kunio zenshu. Vol. 11, 417-546, Tokyo: Chikuma Shobo.

Yanagita, Kunio. Kosho bungeisho ko. In: Yanagita Kunio zenshu. Vol. 8, Yanagita, 1990. Yanagita, Kunio. Momotaro no tan' jo. Tokyo: Sanseido, 1933;

Yanagita Kunio, Keigo Seki. Mukashibanashi saishu techo. Tokyo: Minkan Densho no Kai, 1936

Yanagita, Kunio. Yanagita Kunio zenshu. Vol. 6. Tokyo: Chikuma shobo, 1997.

Yanagita, Kunio. Nihon mukashibanashi meii, Tokyo: Nihon Hoso shuppan Kyokai, 1948. Yanagita, Kunio. Sanjin gaiden shiryo. Kyodo kenkyu, March, April, August, September 1913. In Yanagita Kunio zenshu. Vol. 4, 385-418, Tokyo: Chikuma Shobo.

ZolBroD, Leon M. Takizawa Bakin, 1767-1848. A Restoration that Failed. Monumenta Nipponica Vol. 21. No. 1². 1966.

Danijela B. Vasic

\section{A TINY FOLK TAЛE HERO - MOMOTARO, AS A SYMBOL OF JAPANESE NATIONALISM}

S u m m a r y

Like many other oral traditions, the Japanese one also has a tiny hero who fights against fantastic enemies. "Momotaro", a folk tale about the Peach Boy, emphasizes the national identity of Japanese people. It was very important during the creation of folklore studies in Japan. At the time of the samurai class domination, the folk tale emphasized loyalty, justice and filial piety. With the restoration of monarchy, it was used for the purpose of propagating the mythical roots of Japanese people, as well as of loyalty to the emperor. In times of war Momotaro's opponents were shaped according to the situation, with the support of Japanese nationalists. Demons (oni) became bearded Russians or corrupted British soldiers, and American president was depicted as a leader of a demonic nation. Moreover, in the "Momotaro" folktale Japanese authorities found the justification for their colonialist efforts to appropriate the natural resources of other states.

Универзитет у Београду

Филолошки факултет

Катедра за оријенталистику

Група за јапански језик, књижевности и културу

vasic.danijela@fil.bg.ac.rs 